\title{
Exosomes in Cancer Diagnostics
}

\author{
Young Hwa Soung, Shane Ford, Vincent Zhang and Jun Chung * \\ Department of Pathology, Stony Brook Medicine, 101 Nicolls Road, Stony Brook, NY 11794, USA; \\ younghwa.song@stonybrookmedicine.edu (Y.H.S.); shane.ford@stonybrook.edu (S.F.); \\ vincent.zhang@stonybrook.edu (V.Z.) \\ * Correspondence: jun.chung@stonybrookmedicine.edu; Tel.: +1-631-444-3000; Fax: +1-631-444-3424
}

Academic Editor: Samuel C. Mok

Received: 29 November 2016; Accepted: 9 January 2017; Published: 12 January 2017

\begin{abstract}
Exosomes are endosome derived extracellular vesicles of 30-120 nm size ranges. Exosomes have been identified as mediators of cell-to-cell communication by transferring bioactive molecules such as nucleic acids, proteins and lipids into recipient cells. While exosomes are secreted by multiple cell types, cancer derived exosomes not only influence the invasive potentials of proximally located cells, but also affect distantly located tissues. Based on their ability to alter tumor microenvironment by regulating immunity, angiogenesis and metastasis, there has been growing interest in defining the clinical relevance of exosomes in cancers. In particular, exosomes are valuable sources for biomarkers due to selective cargo loading and resemblance to their parental cells. In this review, we summarize the recent findings to utilize exosomes as cancer biomarkers for early detection, diagnosis and therapy selection.
\end{abstract}

Keywords: exosomes; cancer; biomarkers

\section{Introduction}

Exosomes are small sized $(30-120 \mathrm{~nm})$ extracellular vesicles (EVs) with a multi-vesicular endosomal origin [1-3]. Exosomes are distinguished from microvesicles that are heterogeneous in size (50-1500 nm) and shed directly from the budding of the plasma membrane [4,5]. Exosomes play an essential role in cell-to-cell communication by carrying their contents, including proteins, metabolites, RNAs (mRNA, miRNA, long non coding RNA), DNAs (mtDNA, ssDNA, dsDNA) and lipids [6,7]. Intercellular communication mediated by exosomes not only participates in the regulation of normal physiological processes, but also in pathological processes of many diseases including cancer [8-10]. They are secreted from most cell types and released in bodily fluids such as urine, plasma, saliva, and breast milk [7,11].

Due to their presence and stability in most bodily fluids and resemblance of their contents to parental cells, exosomes have a great potential to serve as a liquid biopsy tool for various diseases $[12,13]$. In particular, cancer derived exosomes likely serves as biomarker for early detection of cancer as they carry the cargo reflective of genetic or signaling alterations in cancer cells of origin [14-16]. Exosome based liquid biopsy merits consideration over conventional tissue biopsy for following reasons. It provides the convenient and non-invasive way of diagnosis over tissue biopsy that requires surgery. The small sample size of tissue biopsy cannot provide the detailed information of genetic heterogeneity within the primary tumor or metastasized secondary tumors. However, exosomes shed from heterogeneous cancers can be collected at once and provide the dynamic information from the tumors at the time of blood drawing. In this review, we summarize the recent progress of the studies that identify exosome-derived analytes that represent a molecular signature of altered states of cancers for diagnostic purposes. Strategies for isolating exosomes will be presented with an emphasis on their clinical use. 


\section{Isolation of Exosomes}

The major hurdle in the clinical utilization of exosomes has been the lack of consistent and dependable methods to isolate a pure exosome population [17]. Therefore, it is essential to overcome technical challenges associates with purifying exosomes to homogeneity free from other subtypes of EVs such as microvesicles and other soluble contaminants to utilize exosomes as cancer biomarkers [18-20]. Greeing et al. evaluated and compared the exosome isolation strategies including differential ultracentrifugation (DC), density-gradient separation (DGS), and affinity capture (AC) procedures [21]. The differential ultracentrifugation (DC) has been widely used as conventional isolation techniques that separate exosomes and other EVs based on their sizes and buoyant density. Cell debris and other objects larger than exosomes and shed microvesicles (sMVs) are removed by $1000 \times g$ centrifugation. Next, over $100,000 \times g$ ultracentrifugation is used to pellet crude exosomes and sMVs mixtures [22]. The downsides of DC include labor and time consuming procedures, a low recovery yield and low specificity, and no separation of exosomes from microvesicle debris, high molecular weight protein oligomers/protein-RNA complexes, and viruses [17,23]. Density-gradient separation (DGS) fractionates EVs based on buoyant density using a discontinuous gradient of a sucrose solution or Opti-prep. While DGS offers higher purity and recovery rate than DC, it still cannot separate exosomes from sMVs or viruses because their buoyant densities overlap [22].

As an alternative strategy to ultracentrifugation, nanomembrane based ultrafiltration and microfiltration were used to successfully isolate urinary exosomes [24,25]. Recently, exosomes from blood serum were successfully isolated by one-step precipitation method by using commercially available reagents such as ExoQuick (System Biosciences, Palo Alto, CA, USA) as an alternative approach to ultracentrifugation [26]. In this study, Rekker et al. found that the ExoQuick precipitation method not only saves time and labor, but is more efficient than ultracentrifugation in exosomal miRNA profiling [26]. Ongoing efforts that combine Enzyme-linked immunosorbent assay (ELISA), Western blotting analysis, Flow cytometry analysis (FACS) and EV arrays are being made to better track EVs based on their biogenesis mechanism (microvesicles with plasma membrane budding vs. exosomes with endocytic origin) [27-29]. These affinity capture (AC) methods target established exosomal markers such as CD63, CD81, TSG 101, HSP 70 and Alix, which allows selective capturing of exosome population followed by detection of cancer specific markers [17].

Affinity capture (AC) approaches rely on exosome surface antigen targeting monoclonal antibody $(\mathrm{mAb})$ that is covalently fused to either magnetic or agarose beads. The multiple reports demonstrated the success of mAbs as baits to isolate exosomes [21,30,31]. In comparison to size-based purification, $\mathrm{AC}$ reduced the contamination of cell-debris, protein aggregates and sMVs from exosomes, and allowed to isolate specific sub-population of exosomes by targeting a specific exosomal surface marker $[30,32,33]$. Tauro et el. performed a proteome study of exosomes isolated from colorectal cancer cell line LIM1863 culture supernatant to evaluate each method mentioned above [22]. They concluded that AC using magnetic beads coated with a mAb targeting exosome surface antigen was far superior to DC and DGS in terms of isolating exosomes [22]. Combination of AC with a microfluidic chip can improve a recovery rate and reduce the sample size to be processed. For example, Chen et al. developed an AC-based microfluidic device that rapidly and selectively capture exosomes from tissue culture and plasma [34]. The AC-based microfluidic device has a great potential for use as a diagnostic tool if it is coupled with downstream analysis techniques to quantify exosomes captured in a device. More examples of microfluidic devices that capture exosomes for diagnostic purposes will be presented in Sections 4 and 5.

\section{Detection of Exosomes}

Another challenge in exosome biology is how to accurately measure the quantity and purity of exosomes. Exosome purity is assessed by measuring exosome-specific marker antigen or protein (i.e., CD63) as a ratio of exosome concentration (i.e., protein to particle ratio) using ELISA assay [27]. Optical methods such as nanoparticle tracking analysis (NTA), dynamic light scattering (DLS) and 
flow cytometry (FACS), as well as non-optical methods including resistive pulse sensing (RPS), surface plasmon resonance (SPR) and transmission electron microscopy (TEM) are currently used to measure vesicles/particle numbers [35].

Malvern has developed NTA-based instruments called Nanosight (LM10, LM20, NS200 and NS500) that allow exosomes to be counted and sized by combining light microscopy and the software that tracks Brownian motion of exosomes. The light scattering mode of Nanosight is used to measure size and its fluorescence mode is used to profile labeled markers in exosomes [36,37]. Nanosight is able to measure particles in the size range of $10 \mathrm{nM}$ to $2 \mu \mathrm{M}$, and concentration within the range of $10^{6}$ to $10^{9}$ particles per mL. NTA method becomes a gold standard to measure the concentration of exosomes and sMVs. The product called Zetasizer Nano ZS (Malvern Instruments Ltd., Malvern, UK) involves DLS technology that determines diameter of EVs including exosomes by measuring the fluctuations from scattering of coherent laser light through suspension of EVs [38]. Nano ZS is specified to measure particles in the size range of $0.3 \mathrm{nM}$ to $1 \mu \mathrm{M}$ and more accurate to measure vesicles with lower size $(<30 \mathrm{nM})$. The limitation of DLS includes the distortion of accuracy by the presence of large particles, and its incompatibility to molecular labeling. Therefore, it is not suitable for molecular profiling of exosomes. Flow cytometry has been used to resolve individual exosomes and measure multiple surface markers per exosomes [39]. However, due to the smaller sizes of EV's relative cells, only the particles larger than $300 \mathrm{~nm}$ can be resolved.

Regarding to non-optical methods, TEM overcomes the limitation of the conventional light microscope to resolve exosomes as diameter of exosomes is less than optical wavelength. TEM can resolve individual exosomes due to short wavelength of electrons [40]. TEM can serve as a nice complementary technique to the optical methods mentioned to above by providing morphology of exosomes to be resolved. The RPS method allows measuring single nanoparticles as they are driven through a nanopore [41,42]. A transient change in the ionic current flow is generated while the particles flows through the pore and the change in current is proportional to the size of the particle. Maas et al. demonstrated the tunable resistive pulse sensing (tRPS) platform for direct quantification and size characterization of EVs by using the product called qNano system [43]. This method is ideal for direct quantification of exosomes or microvesicles from bodily fluids as isolation or manipulation of EVs is not required. SPR-based nanosensors recently garnered a lot of attention due to their ability to detect small numbers of molecules [44]. Im et al. developed SPR-based exosome sensor called nano-plasmonic exosome (nPLEX) [45]. Each nanohole array of nPLEX is functionalized with antibodies that recognize exosome surface proteins. nPLEX has been used to differentiate ascites samples from ovarian cancer patients from healthy controls as ovarian cancer cell-derived exosomes were identified for their expression of CD24 and EpCAM [45].

\section{Exosomal Surface Proteins as Cancer Biomarkers}

Exosomes contain a variety of proteins that reflect their origin and alteration of the parental cells. Based on endosome-based biogenesis pathway, exosome specific protein markers include endosome associated proteins (e.g., small Rab family GTPases, annexins and flotillin), proteins involved in exosome biogenesis (e.g., Alix, Tsg101 and ESCRT complex), tetraspanins (e.g., CD9, CD37, CD53, CD63, CD81 and CD82), heat shock proteins (Hsp70, Hsp90) and epithelial cell adhesion molecules (EpCam) [46-49]. These proteins can serve as putative common exosome markers that can be used to isolate exosomes by immune-affinity capture methods or to measure the purity of an exosome population by Western blotting analysis after isolation procedure. Based on exosome isolation techniques mentioned above, the subsequent studies on proteomic analyses of cancer-derived exosomes led to the identification of potential exosomal markers to serve as a liquid biopsy in breast, prostate, pancreatic, ovarian, colorectal cancers and glioblastoma [15,50-60] (Table 1).

A number of exosomal breast cancer markers have been identified in recent years. Rupp et al. characterized CD24 and EpCAM as tumor-derived exosome markers by using immune-affinity isolation techniques involving anti-CD24 and anti-EpCAM magnetic beads [53]. In exosomes-derived 
from breast cancer patient serum, only CD24 was detectable, but EpCAM was absent due to metalloproteinase-dependent cleavage [53]. The outcome indicated that exosomal CD24 could serve as a circulating breast cancer biomarker. Moon et al. demonstrated that both EDIL3 and fibronectin in circulating EVs (mostly exosome population) can serve as promising biomarkers of early stage breast cancer by using ELISA methods [50,51]. The levels of exosomal EDIL3 and fibronectin from breast cancer patients who underwent surgery were dramatically reduced, suggesting that EDIL3 and fibronectin in circulating EVs can also serve as treatment response markers [50,51].

Table 1. Exosomal protein biomarkers from body fluids of patients in pre-clinical and clinical studies.

\begin{tabular}{|c|c|c|c|c|c|}
\hline $\begin{array}{l}\text { Exosomal } \\
\text { Protein }\end{array}$ & Tumor & Body Fluid & Isolation/Detection Method & Application & Reference \\
\hline CD24, EpCAM & Breast & $\begin{array}{c}\text { Serum, } \\
\text { Ascites fluid }\end{array}$ & $\begin{array}{l}\text { Ultracentrifugation and sucrose } \\
\text { gradient/MACs using } \\
\text { anti-EpCAM beads }\end{array}$ & Early diagnosis & [53] \\
\hline EDIL3 & Breast & Plasma & ELISA & Diagnosis/monitoring & [50] \\
\hline Fibronectin & Breast & Plasma & ELISA & Early diagnosis & [51] \\
\hline $\begin{array}{c}\text { Survivin } \\
\text { (Survivn 2B) }\end{array}$ & Breast & Serum & ExoQuick and ELISA & Diagnosis/prognosis & [55] \\
\hline Survivin & Prostate & Plasma/Serum & $\begin{array}{l}\text { Ultracentrifugation (plasma) } \\
\text { ExoQuick (Serum) }\end{array}$ & Early diagnosis & [54] \\
\hline $\begin{array}{c}\text { PCA-3, } \\
\text { TMPRSS2:ERG }\end{array}$ & Prostate & Urine & $\begin{array}{c}\text { Filtration and } \\
\text { ultracentrifugation }\end{array}$ & Diagnosis/monitoring & [57] \\
\hline Glypican-1 & Pancreatic & Serum & Ultracentrifugation and FACS & Early diagnosis & [15] \\
\hline $\begin{array}{c}\text { TGF } \beta 1, \\
\text { MAGE } 3 / 6\end{array}$ & Ovarian & Plasma & $\begin{array}{c}\text { Filtration and } \\
\text { ultracentrifugation }\end{array}$ & $\begin{array}{l}\text { Prognosis/therapy } \\
\text { monitoring }\end{array}$ & [58] \\
\hline $\begin{array}{l}\text { CD24, EpCAM, } \\
\text { CA-125 }\end{array}$ & Ovarian & Plasma & $\begin{array}{l}\text { Microfluidic continuous-flow } \\
\text { platform (ExoSearch chip) }\end{array}$ & Diagnosis & [52] \\
\hline $\begin{array}{l}\text { EGFR, } \\
\text { EGFRvIII, } \\
\text { CD63 }\end{array}$ & Glioblastoma & Serum & $\begin{array}{c}\text { Target-specific magnetic } \\
\text { nanoparticles (MNPs) and } \\
\mu \text { NMR system }\end{array}$ & $\begin{array}{l}\text { Therapy monitoring } \\
\text { and prediction }\end{array}$ & [60] \\
\hline CD147, CD9 & Colorectal & Serum & $\begin{array}{c}\text { ExoScreen using } \\
\text { photosensitizer-beads }\end{array}$ & Diagnosis & [61] \\
\hline
\end{tabular}

In addition to breast cancer, exosomal proteins provide the useful source for biomarkers for a number of other cancers. Khan et al. found that Survivin, a member of inhibitor of apoptosis (IAP), was detectable in plasma-derived exosomes from both normal and prostate cancer patients, but the relative amount of exosomal Survivin is significantly higher in plasma of prostate cancer patients [54]. Plasma-derived exosomes were isolated by ultracentrifugation, followed by ELISA and Western blotting analysis to measure the amount of exosomal Survivin in this study. The subsequent study by Khan et al. showed that exosomal Survivin and its alternative splice variants were also elevated in breast cancer plasma [55], suggesting that exosomal Survivin is an important diagnostic markers for a number of cancers. Urinary exosomes, which are readily accessible by non-invasive means, have been utilized to develop biomarkers for prostate cancer and bladder cancer. Protein profiling of urinary exosomes from healthy and bladder cancer patients by label-free liquid chromatography-tandem mass spectrometry (LC-MS/MS) led to identification of eight urinary exosomal proteins as potential biomarkers for bladder cancer [56]. Nilsson et al. demonstrated that PCA3 and TMPRSS2:ERG, two established prostate cancer markers, are also present in urinary exosomes from prostate cancer patients [57]. Glypican-1, the cell surface proteoglycan, was shown to be present in exosomes isolated by FACS from serum of pancreatic patients in both early and late stages, but not in benign pancreatic disease [15]. Exosomes isolated by ultracentrifugation from ovarian cancer patients' plasma carried TGF- $\beta 1$ and MAGE 3/6, but not in exosomes from patients with benign tumors [58]. 
A number of recent studies reported the success of developing the rapid and high-throughput platform for clinical utilization of exosome-based diagnostics without a purification of exosomes. Kanwar et al. [59] developed "ExoChip", a microfluidic device that captures and stains exosomes with CD63 antibody and a fluorescent dye. This technology allows quantification of exosomes in standard plate reader and profiling of exosomal miRNA analysis [59]. A microfluidic chip labeled with target (CD63, EGFR, EGFRvIII) specific magnetic nanosensor was used in profiling microvesicles for diagnosis of glioblastoma multitome [60]. Yoshioka et al. [61] established the highly rapid and analytical technique called "ExoScreen" that are comprised of CD9 and CD147 antibodies and photosensitizing beads. "ExoScreen" can detect CD9 and CD147 double positive EVs that are enriched in tissue culture media of colorectal cancer cells and serum from colorectal cancer patients [61]. Zhao et al. developed a simpler microfluidic device called "ExoSearch" chip that allows quantitative isolation of exosmes by using immunomagnetic beads. "ExoSearch" chip was used for liquid biopsy of ovarian cancer by measuring three exosomal tumor protein markers such as CA-125, EpCam and CD24 [52]. Consequently, the advancement of immune-capturing systems in microchips led to a highly sensitive and reproducible detection of circulating cancer markers without using a large volume of samples and time consuming isolation processes of exosomes.

\section{Exosomal Nucleic Acids as Cancer Biomarkers}

Initial analyses of nucleic acids from isolated exosomes identified microRNAs (miRs) and mRNAs as the major components of exosomal cargo [62,63]. Subsequent studies revealed that exosomes contain other species of RNAs such as transfer RNAs (tRNAs) and long noncoding RNAs (lnc RNAs) [64,65]. In addition to RNA species, fragments of both single stranded and double stranded DNAs were identified in exosomes [66,67]. Exosomal miRNAs have been under the most attention among exosomal nucleic acids as cancer diagnosis biomarkers due to their stability against RNase-dependent degradation [68-70].

Since the discovery of exosomal miRNAs by Valadi et al. in 2007 [62], pioneering studies have been done to characterize exosomal miRNA as diagnostic markers for cancers. Taylor et al. found that eight miRNAs (miR-21, miR-141, miR-200a, miR-200c, miR-200b, miR-203, miR-205 and miR-214), previously known diagnostic markers for ovarian cancer, were also present in circulating tumor exosomes from ovarian cancer patients [68]. Rabinowits et al. [71] performed miRNA-profiling anaylsis on tumor biopsy samples, exosomes isolated from lung cancer patients and control groups. The study demonstrated the similarity of miRNA patterns between exosomes and tumor biopsy samples from lung cancer patients, but these miRNA patterns were significant different from those of exosomes in control group [71]. It suggested that the potentials of circulating exosomal miRNAs as liquid biopsy markers for lung adenocarcinoma [71]. Several miRNAs showed their potentials as diagnostic markers for esophageal squamous cell cancer (ESCC). Tanaka et al. found that the levels of exosomal miR-21 from ESCC patients were significantly higher than those of patients with benign diseases [72]. Exosomal miR-21 levels also correlate with tumor progression and aggressiveness, suggesting that exosomal miR-21 can serve as biomarker as well as therapeutic target [72]. Exosomal miR-1246 was also identified as diagnostic and prognostic markers for ESCC [73]. While exosomal miR-1246 was significantly elevated in serum of ESCC patients, its level is not increased in tumor biopsy samples, suggesting that exosomal miRNA levels may not necessarily reflect the abundance in the cell of origin [73].

During the last three years, more exosomal miRNAs were identified by using a combination of ExoQuick (System Bioscience) precipitation, ultracentrifugation and commercialized Exo-miR kit (Bioo Scientific, Austin, TX, USA) and RNA seq-based miRNA profiling methods in a number of cancer models including breast, colon, prostate, pancreatic cancers and glioblastoma [74-80]. Table 2 summarizes the candidate exosomal miRNA markers reported up to date for diagnostic tools for these cancers. 
Exosomal DNAs merit consideration as a diagnostic tool as well, due to their ability to carry information regarding cancer specific mutations [66,81]. Kahlert et al. identified the large fragments of double stranded genomic DNA ( $>10 \mathrm{~kb})$ in exosomes from pancreatic cancer cell lines and pancreatic cancer patients. The whole genomic sequencing revealed the mutations in KRAS and p53 in genomic DNA of pancreatic cancer-derived exosomes, indicating the usage of exosomal DNA sequencing to predict the treatment option and therapy resistance [81].

Table 2. Exosomal nucleic acid biomarkers in pre-clinical and clinical studies.

\begin{tabular}{|c|c|c|c|c|c|}
\hline Exosomal NA & Tumor & $\begin{array}{l}\text { Body } \\
\text { Fluid }\end{array}$ & Isolation/Detection Method & Application & Reference \\
\hline miR-101, miR-372, miR-373 & Breast & Serum & ExoQuick/qRT-PCR & Diagnosis for TNBC & [75] \\
\hline miR-21, miR-1246 & Breast & Plasma & ExoQuick/qRT-PCR & Diagnosis & [76] \\
\hline miR-21 & $\begin{array}{l}\text { Esophageal squamous } \\
\text { cell carcinoma }\end{array}$ & Plasma & ExoQuick/qRT-PCR & $\begin{array}{c}\text { Early diagnosis } \\
\text { and therapy }\end{array}$ & [72] \\
\hline $\begin{array}{l}\text { miR-21, miR-141, miR-200a, } \\
\text { miR-200c, miR-200b, } \\
\text { miR-203, miR-205, miR-214 }\end{array}$ & Ovarian & Serum & $\begin{array}{l}\text { Magnetic activated cell } \\
\text { sorting (MACs) using } \\
\text { anti-EpCAM array }\end{array}$ & $\begin{array}{c}\text { Diagnosis and } \\
\text { screening of stage }\end{array}$ & [68] \\
\hline $\operatorname{miR}-4772-3 p$ & Colon & Serum & ExoQuick/qRT-PCR & $\begin{array}{c}\text { Prognosis for } \\
\text { recurrent stage II, III }\end{array}$ & [76] \\
\hline $\begin{array}{c}\text { let-7a, miR-1229, } \\
\text { miR-1246, miR-150, miR-21, } \\
\text { miR-223, miR-23a }\end{array}$ & Colon & Serum & Ultracentrifugation/qRT-PCR & Diagnosis & [77] \\
\hline miR141, miR-375 & Prostate & $\begin{array}{l}\text { Serum, } \\
\text { plasma }\end{array}$ & $\begin{array}{c}\text { ExoMiR extraction kit (Serum) } \\
\text { Qiagen miRNeasy } \\
\text { (Plasma)/qRT-PCR }\end{array}$ & Diagnosis & [78] \\
\hline miR-17-5p, miR-21 & Pancreatic & $\begin{array}{l}\text { Serum, } \\
\text { urine }\end{array}$ & $\begin{array}{c}\text { Filtration and } \\
\text { Ultracentrifugation/qRT-PCR }\end{array}$ & Diagnosis & [79] \\
\hline Mutated KRAS DNA & Pancreatic & Serum & $\begin{array}{c}\text { Filtration and } \\
\text { Ultracentrifugation/PCR and } \\
\text { genome sequencing }\end{array}$ & $\begin{array}{l}\text { Diagnosis/prognosis } \\
\text { for personalized } \\
\text { medicine }\end{array}$ & [66] \\
\hline $\begin{array}{l}\text { Snc RNA (RNU6-1) miR-320, } \\
\text { miR-574-3p }\end{array}$ & Glioblastoma & Serum & $\begin{array}{c}\text { ExoQuick/ } \\
\text { qRT-PCR-based array }\end{array}$ & Early diagnosis & [80] \\
\hline
\end{tabular}

\section{Conclusions and Future Direction}

Cancer-derived exosomes contribute to cancer progression through enhancing intercellular transfer of cargo that contains proteins, lipids and nucleic acids within the tumor microenvironment. The cargo of exosomes reflects the altered state of original cancers, which qualifies exosomes as minimally invasive biomarkers for early detection, diagnosis and prognosis. Compelling recent literature supports that exosome-based diagnostics provide higher sensitivity and specificity over conventional biopsy or liquid biopsy biomarkers due to their stability in biofluids. In addition, exosomal markers are readily available from most biofluids and recent advances in technology in exosome isolation make exosome-based diagnostics cost and labor effective.

The major obstacle to overcome in the field of exosome diagnostics is to develop optimal methods to isolate pure exosome population. Microvesicle themselves can be a useful diagnostic tool to detect cancers, but the comparison studies will only be possible with isolation techniques that separate these two major EVs into pure exosomal vs. microvesicle populations. Another challenge is to understand the mechanisms that regulate the heterogeneity of cancer exosomes, which will affect the contents of cancer-derived exosomal cargo, and therefore influence the reproducibility of diagnostic outcomes. Despite these concerns, future efforts that combine next generation sequencing of exosomal RNAs and DNAs, proteomic analysis of exosomal surface proteins, and immune-affinity capturing techniques will reach to the next level of exosome utilization for cancer diagnosis.

Acknowledgments: This research was supported by the grants of American Cancer Society (RSG-09-091-01-CSM: PI, Jun Chung) and NIH-NCI (R01CA163657-01A1: PI, Jun Chung).

Conflicts of Interest: The authors declare no conflict of interest. 


\section{References}

1. Tkach, M.; Théry, C. Communication by extracellular vesicles: Where we are and where we need to go. Cell 2016, 164, 1226-1232. [CrossRef] [PubMed]

2. Théry, C.; Zitvogel, L.; Amigorena, S. Exosomes: Composition, biogenesis and function. Nat. Rev. Immunol. 2002, 2, 569-579. [PubMed]

3. Keller, S.; Sanderson, M.P.; Stoeck, A.; Altevogt, P. Exosomes: From biogenesis and secretion to biological function. Immunol. Lett. 2006, 107, 102-108. [CrossRef] [PubMed]

4. Colombo, M.; Raposo, G.; Théry, C. Biogenesis, secretion, and intercellular interactions of exosomes and other extracellular vesicles. Annu. Rev. Cell Dev. Biol. 2014, 30, 255-289. [CrossRef] [PubMed]

5. Raposo, G.; Stoorvogel, W. Extracellular vesicles: Exosomes, microvesicles, and friends. J. Cell Biol. 2013. [CrossRef] [PubMed]

6. El, A.S.; Mäger, I.; Breakefield, X.O.; Wood, M.J.A. Extracellular vesicles: Biology and emerging therapeutic opportunities. Nat. Rev. Drug Discov. 2013, 12, 347-357.

7. De Toro, J.; Herschlik, L.; Waldner, C.; Mongini, C. Emerging roles of exosomes in normal and pathological conditions: New insights for diagnosis and therapeutic applications. Front. Immunol. 2015. [CrossRef] [PubMed]

8. Meckes, D.G. Exosomal communication goes viral. J. Virol. 2015, 89, 5200-5203. [CrossRef] [PubMed]

9. Barteneva, N.S.; Maltsev, N.; Vorobjev, I.A. Microvesicles and intercellular communication in the context of parasitism. Front. Cell. Infect. Microbiol. 2013. [CrossRef] [PubMed]

10. Kucharzewska, P.; Belting, M. Emerging roles of extracellular vesicles in the adaptive response of tumour cells to microenvironmental stress. J. Extracell. Vesicles 2013, 2, 1-10. [CrossRef] [PubMed]

11. Lee, Y.; El Andaloussi, S.; Wood, M.J.A. Exosomes and microvesicles: Extracellular vesicles for genetic information transfer and gene therapy. Hum. Mol. Genet. 2012, 21, R125-R134. [CrossRef] [PubMed]

12. Rak, J. Extracellular vesicles-Biomarkers and effectors of the cellular interactome in cancer. Front. Pharmacol. 2013. [CrossRef] [PubMed]

13. Hornick, N.I.; Huan, J.; Doron, B.; Goloviznina, N.A.; Lapidus, J.; Chang, B.H.; Kurre, P. Serum Exosome MicroRNA as a Minimally-Invasive Early Biomarker of AML. Sci. Rep. 2015. [CrossRef] [PubMed]

14. Tang, M.K.S.; Wong, A.S.T. Exosomes: Emerging biomarkers and targets for ovarian cancer. Cancer Lett. 2015, 367, 26-33. [CrossRef] [PubMed]

15. Melo, S.A.; Luecke, L.B.; Kahlert, C.; Fernandez, A.F.; Gammon, S.T.; Kaye, J.; LeBleu, V.S.; Mittendorf, E.A.; Weitz, J.; Rahbari, N.; et al. Glypican-1 identifies cancer exosomes and detects early pancreatic cancer. Nature 2015, 523, 177-182. [CrossRef] [PubMed]

16. Li, Y.; Zheng, Q.; Bao, C.; Li, S.; Guo, W.; Zhao, J.; Chen, D.; Gu, J.; He, X.; Huang, S. Circular RNA is enriched and stable in exosomes: A promising biomarker for cancer diagnosis. Cell Res. 2015, 25, 981-984. [CrossRef] [PubMed]

17. Théry, C.; Amigorena, S.; Raposo, G.; Clayton, A. Isolation and characterization of exosomes from cell culture supernatants and biological fluids. Curr. Protoc. Cell Biol. 2006. [CrossRef]

18. Kowal, J.; Arras, G.; Colombo, M.; Jouve, M.; Morath, J.P.; Primdal-Bengtson, B.; Dingli, F.; Loew, D.; Tkach, M.; Théry, C. Proteomic comparison defines novel markers to characterize heterogeneous populations of extracellular vesicle subtypes. Proc. Natl. Acad. Sci. USA 2016, 113, E968-E977. [CrossRef] [PubMed]

19. Witwer, K.W.; Buzás, E.I.; Bemis, L.T.; Bora, A.; Lässer, C.; Lötvall, J.; Nolte-'t Hoen, E.N.; Piper, M.G.; Sivaraman, S.; Skog, J.; et al. Standardization of sample collection, isolation and analysis methods in extracellular vesicle research. J. Extracell. Vesicles 2013. [CrossRef] [PubMed]

20. Lötvall, J.; Hill, A.F.; Hochberg, F.; Buzás, E.I.; Di Vizio, D.; Gardiner, C.; Gho, Y.S.; Kurochkin, I.V.; Mathivanan, S.; Quesenberry, P.; et al. Minimal experimental requirements for definition of extracellular vesicles and their functions: A position statement from the International Society for Extracellular Vesicles. J. Extracell. Vesicles 2014. [CrossRef] [PubMed]

21. Greening, D.W.; Xu, R.; Ji, H.; Tauro, B.J.; Simpson, R.J. A protocol for exosome isolation and characterization: Evaluation of ultracentrifugation, density-gradient separation, and immunoaffinity capture methods. Methods Mol. Biol. 2015, 1295, 179-209. [PubMed] 
22. Tauro, B.J.; Greening, D.W.; Mathias, R.A.; Ji, H.; Mathivanan, S.; Scott, A.M.; Simpson, R.J. Comparison of ultracentrifugation, density gradient separation, and immunoaffinity capture methods for isolating human colon cancer cell line LIM1863-derived exosomes. Methods 2012, 56, 293-304. [CrossRef] [PubMed]

23. Alvarez, M.L.; Khosroheidari, M.; Kanchi Ravi, R.; DiStefano, J.K. Comparison of protein, microRNA, and mRNA yields using different methods of urinary exosome isolation for the discovery of kidney disease biomarkers. Kidney Int. 2012, 82, 1024-1032. [CrossRef] [PubMed]

24. Cheruvanky, A.; Zhou, H.; Pisitkun, T.; Kopp, J.B.; Knepper, M.A.; Yuen, P.S.T.; Star, R.A. Rapid isolation of urinary exosomal biomarkers using a nanomembrane ultrafiltration concentrator. Am. J. Physiol. Renal Physiol. 2007, 292, F1657-F1661. [CrossRef] [PubMed]

25. Merchant, M.L.; Powell, D.W.; Wilkey, D.W.; Cummins, T.D.; Deegens, J.K.; Rood, I.M.; McAfee, K.J.; Fleischer, C.; Klein, E.; Klein, J.B. Microfiltration isolation of human urinary exosomes for characterization by MS. Proteom. Clin. Appl. 2010, 4, 84-96. [CrossRef] [PubMed]

26. Rekker, K.; Saare, M.; Roost, A.M.; Kubo, A.-L.; Zarovni, N.; Chiesi, A.; Salumets, A.; Peters, M. Comparison of serum exosome isolation methods for microRNA profiling. Clin. Biochem. 2014, 47, 135-138. [CrossRef] [PubMed]

27. Webber, J.; Clayton, A. How pure are your vesicles? J. Extracell. Vesicles 2013. [CrossRef] [PubMed]

28. Erdbrügger, U.; Lannigan, J. Analytical challenges of extracellular vesicle detection: A comparison of different techniques. Cytom. J. Int. Soc. Anal. Cytol. 2016, 89, 123-134. [CrossRef] [PubMed]

29. Gagni, P.; Cretich, M.; Benussi, L.; Tonoli, E.; Ciani, M.; Ghidoni, R.; Santini, B.; Galbiati, E.; Prosperi, D.; Chiari, M. Combined mass quantitation and phenotyping of intact extracellular vesicles by a microarray platform. Anal. Chim. Acta 2016, 902, 160-167. [CrossRef] [PubMed]

30. Mathivanan, S.; Lim, J.W.E.; Tauro, B.J.; Ji, H.; Moritz, R.L.; Simpson, R.J. Proteomics analysis of A33 immunoaffinity-purified exosomes released from the human colon tumor cell line LIM1215 reveals a tissue-specific protein signature. Mol. Cell. Proteom. MCP 2010, 9, 197-208. [CrossRef] [PubMed]

31. Liga, A.; Vliegenthart, A.D.B.; Oosthuyzen, W.; Dear, J.W.; Kersaudy-Kerhoas, M. Exosome isolation: A microfluidic road-map. Lab Chip 2015, 15, 2388-2394. [CrossRef] [PubMed]

32. Bobrie, A.; Colombo, M.; Krumeich, S.; Raposo, G.; Théry, C. Diverse subpopulations of vesicles secreted by different intracellular mechanisms are present in exosome preparations obtained by differential ultracentrifugation. J. Extracell. Vesicles 2012. [CrossRef] [PubMed]

33. Vaidyanathan, R.; Naghibosadat, M.; Rauf, S.; Korbie, D.; Carrascosa, L.G.; Shiddiky, M.J.A.; Trau, M. Detecting exosomes specifically: A multiplexed device based on alternating current electrohydrodynamic induced nanoshearing. Anal. Chem. 2014, 86, 11125-11132. [CrossRef] [PubMed]

34. Chen, C.; Skog, J.; Hsu, C.-H.; Lessard, R.T.; Balaj, L.; Wurdinger, T.; Carter, B.S.; Breakefield, X.O.; Toner, M.; Irimia, D. Microfluidic isolation and transcriptome analysis of serum microvesicles. Lab Chip 2010, 10, 505-511. [CrossRef] [PubMed]

35. Smith, Z.J.; Lee, C.; Rojalin, T.; Carney, R.P.; Hazari, S.; Knudson, A.; Lam, K.; Saari, H.; Ibañez, E.L.; Viitala, T.; et al. Single exosome study reveals subpopulations distributed among cell lines with variability related to membrane content. J. Extracell. Vesicles 2015. [CrossRef] [PubMed]

36. Soo, C.Y.; Song, Y.; Zheng, Y.; Campbell, E.C.; Riches, A.C.; Gunn-Moore, F.; Powis, S.J. Nanoparticle tracking analysis monitors microvesicle and exosome secretion from immune cells. Immunology 2012, 136, 192-197. [CrossRef] [PubMed]

37. Gercel-Taylor, C.; Atay, S.; Tullis, R.H.; Kesimer, M.; Taylor, D.D. Nanoparticle analysis of circulating cell-derived vesicles in ovarian cancer patients. Anal. Biochem. 2012, 428, 44-53. [CrossRef] [PubMed]

38. Sokolova, V.; Ludwig, A.-K.; Hornung, S.; Rotan, O.; Horn, P.A.; Epple, M.; Giebel, B. Characterisation of exosomes derived from human cells by nanoparticle tracking analysis and scanning electron microscopy. Colloids Surf. B Biointerfaces 2011, 87, 146-150. [CrossRef] [PubMed]

39. Orozco, A.F.; Lewis, D.E. Flow cytometric analysis of circulating microparticles in plasma. Cytom. J. Int. Soc. Anal. Cytol. 2010, 77, 502-514. [CrossRef] [PubMed]

40. Van der Pol, E.; Hoekstra, A.G.; Sturk, A.; Otto, C.; van Leeuwen, T.G.; Nieuwland, R. Optical and non-optical methods for detection and characterization of microparticles and exosomes. J. Thromb. Haemost. JTH 2010, 8 , 2596-2607. [CrossRef] [PubMed] 
41. Maas, S.L.N.; de Vrij, J.; van der Vlist, E.J.; Geragousian, B.; van Bloois, L.; Mastrobattista, E.; Schiffelers, R.M.; Wauben, M.H.M.; Broekman, M.L.D.; Nolte-'t Hoen, E.N.M. Possibilities and limitations of current technologies for quantification of biological extracellular vesicles and synthetic mimics. J. Control. Release 2015, 200, 87-96. [CrossRef] [PubMed]

42. Van der Pol, E.; Coumans, F.A.W.; Grootemaat, A.E.; Gardiner, C.; Sargent, I.L.; Harrison, P.; Sturk, A.; van Leeuwen, T.G.; Nieuwland, R. Particle size distribution of exosomes and microvesicles determined by transmission electron microscopy, flow cytometry, nanoparticle tracking analysis, and resistive pulse sensing. J. Thromb. Haemost. JTH 2014, 12, 1182-1192. [CrossRef] [PubMed]

43. Maas, S.L.N.; De Vrij, J.; Broekman, M.L.D. Quantification and size-profiling of extracellular vesicles using tunable resistive pulse sensing. J. Vis. Exp. JoVE 2014. [CrossRef] [PubMed]

44. Kravets, V.G.; Schedin, F.; Jalil, R.; Britnell, L.; Gorbachev, R.V.; Ansell, D.; Thackray, B.; Novoselov, K.S.; Geim, A.K.; Kabashin, A.V.; et al. Singular phase nano-optics in plasmonic metamaterials for label-free single-molecule detection. Nat. Mater. 2013, 12, 304-309. [CrossRef] [PubMed]

45. Im, H.; Shao, H.; Park, Y.I.; Peterson, V.M.; Castro, C.M.; Weissleder, R.; Lee, H. Label-free detection and molecular profiling of exosomes with a nano-plasmonic sensor. Nat. Biotechnol. 2014, 32, 490-495. [CrossRef] [PubMed]

46. Mathivana, S.; Ji, H.; Simpson, R.J. Exosomes: Extracellular organelles important in intercellular communication. J. Proteom. 2010, 73, 1907-1920. [CrossRef] [PubMed]

47. Kowal, J.; Tkach, M.; Théry, C. Biogenesis and secretion of exosomes. Curr. Opin. Cell Biol. 2014, $29,116-125$. [CrossRef] [PubMed]

48. Simons, M.; Raposo, G. Exosomes-Vesicular carriers for intercellular communication. Curr. Opin. Cell Biol. 2009, 21, 575-581. [CrossRef] [PubMed]

49. Runz, S.; Keller, S.; Rupp, C.; Stoeck, A.; Issa, Y.; Koensgen, D.; Mustea, A.; Sehouli, J.; Kristiansen, G.; Altevogt, P. Malignant ascites-derived exosomes of ovarian carcinoma patients contain CD24 and EpCAM. Gynecol. Oncol. 2007, 107, 563-571. [CrossRef] [PubMed]

50. Moon, P.-G.; Lee, J.-E.; Cho, Y.-E.; Lee, S.J.; Jung, J.H.; Chae, Y.S.; Bae, H.-I.; Kim, Y.-B.; Kim, I.-S.; Park, H.Y.; et al. Identification of developmental endothelial locus-1 on circulating extracellular vesicles as a novel biomarker for early breast cancer detection. Clin. Cancer Res. 2016, 22, 1757-1766. [CrossRef] [PubMed]

51. Moon, P.-G.; Lee, J.-E.; Cho, Y.-E.; Lee, S.J.; Chae, Y.S.; Jung, J.H.; Kim, I.-S.; Park, H.Y.; Baek, M.-C. Fibronectin on circulating extracellular vesicles as a liquid biopsy to detect breast cancer. Oncotarget 2016, 7, 40189-40199. [CrossRef] [PubMed]

52. Zhao, Z.; Yang, Y.; Zeng, Y.; He, M. A microfluidic ExoSearch chip for multiplexed exosome detection towards blood-based ovarian cancer diagnosis. Lab Chip 2016, 16, 489-496. [CrossRef] [PubMed]

53. Rupp, A.-K.; Rupp, C.; Keller, S.; Brase, J.C.; Ehehalt, R.; Fogel, M.; Moldenhauer, G.; Marmé, F.; Sültmann, H.; Altevogt, P. Loss of EpCAM expression in breast cancer derived serum exosomes: Role of proteolytic cleavage. Gynecol. Oncol. 2011, 122, 437-446. [CrossRef] [PubMed]

54. Khan, S.; Jutzy, J.M.S.; Valenzuela, M.M.A.; Turay, D.; Aspe, J.R.; Ashok, A.; Mirshahidi, S.; Mercola, D.; Lilly, M.B.; Wall, N.R. Plasma-derived exosomal survivin, a plausible biomarker for early detection of prostate cancer. PLoS ONE 2012, 7, e46737. [CrossRef] [PubMed]

55. Khan, S.; Bennit, H.F.; Turay, D.; Perez, M.; Mirshahidi, S.; Yuan, Y.; Wall, N.R. Early diagnostic value of survivin and its alternative splice variants in breast cancer. BMC Cancer 2014. [CrossRef] [PubMed]

56. Smalley, D.M.; Sheman, N.E.; Nelson, K.; Theodorescu, D. Isolation and identification of potential urinary microparticle biomarkers of bladder cancer. J. Proteome Res. 2008, 7, 2088-2096. [CrossRef] [PubMed]

57. Nilsson, J.; Skog, J.; Nordstrand, A.; Baranov, V.; Mincheva-Nilsson, L.; Breakefield, X.O.; Widmark, A. Prostate cancer-derived urine exosomes: A novel approach to biomarkers for prostate cancer. Br. J. Cancer 2009, 100, 1603-1607. [CrossRef] [PubMed]

58. Szajnik, M.; Derbis, M.; Lach, M.; Patalas, P.; Michalak, M.; Drzewiecka, H.; Szpurek, D.; Nowakowski, A.; Spaczynski, M.; Baranowski, W.; et al. Exosomes in Plasma of Patients with Ovarian Carcinoma: Potential Biomarkers of Tumor Progression and Response to Therapy. Gynecol. Obstet. 2013. [CrossRef]

59. Kanwar, S.S.; Dunlay, C.J.; Simeone, D.M.; Nagrath, S. Microfluidic device (ExoChip) for on-chip isolation, quantification and characterization of circulating exosomes. Lab Chip 2014, 14, 1891-1900. [CrossRef] [PubMed] 
60. Shao, H.; Chung, J.; Balaj, L.; Charest, A.; Bigner, D.D.; Carter, B.S.; Hochberg, F.H.; Breakefield, X.O.; Weissleder, R.; Lee, H. Protein typing of circulating microvesicles allows real-time monitoring of glioblastoma therapy. Nat. Med. 2012, 18, 1835-1840. [CrossRef] [PubMed]

61. Yoshioka, Y.; Kosaka, N.; Konishi, Y.; Ohta, H.; Okamoto, H.; Sonoda, H.; Nonaka, R.; Yamamoto, H.; Ishii, H.; Mori, M.; et al. Ultra-sensitive liquid biopsy of circulating extracellular vesicles using ExoScreen. Nat. Commun. 2014. [CrossRef] [PubMed]

62. Valadi, H.; Ekström, K.; Bossios, A.; Sjöstrand, M.; Lee, J.J.; Lötvall, J.O. Exosome-mediated transfer of mRNAs and microRNAs is a novel mechanism of genetic exchange between cells. Nat. Cell Biol. 2007, 9, 654-659. [CrossRef] [PubMed]

63. Ratajczak, J.; Wysoczynski, M.; Hayek, F.; Janowska-Wieczorek, A.; Ratajczak, M.Z. Membrane-derived microvesicles: Important and underappreciated mediators of cell-to-cell communication. Leukemia 2006, 20, 1487-1495. [CrossRef] [PubMed]

64. Gusachenko, O.N.; Zenkova, M.A.; Vlassov, V.V. Nucleic acids in exosomes: Disease markers and intercellular communication molecules. Biochem. Biokhimiia 2013, 78, 1-7. [CrossRef] [PubMed]

65. Bullock, M.D.; Silva, A.M.; Kanlikilicer-Unaldi, P.; Filant, J.; Rashed, M.H.; Sood, A.K.; Lopez-Berestein, G.; Calin, G.A. Exosomal Non-Coding RNAs: Diagnostic, Prognostic and Therapeutic Applications in Cancer. Non-Coding RNA 2015, 1, 53-68. [CrossRef]

66. Kahlert, C.; Melo, S.A.; Protopopov, A.; Tang, J.; Seth, S.; Koch, M.; Zhang, J.; Weitz, J.; Chin, L.; Futreal, A.; et al. Identification of double-stranded genomic DNA spanning all chromosomes with mutated KRAS and p53 DNA in the serum exosomes of patients with pancreatic cancer. J. Biol. Chem. 2014, 289, 3869-3875. [CrossRef] [PubMed]

67. Balaj, L.; Lessard, R.; Dai, L.; Cho, Y.-J.; Pomeroy, S.L.; Breakefield, X.O.; Skog, J. Tumour microvesicles contain retrotransposon elements and amplified oncogene sequences. Nat. Commun. 2011. [CrossRef] [PubMed]

68. Taylor, D.D.; Gercel-Taylor, C. MicroRNA signatures of tumor-derived exosomes as diagnostic biomarkers of ovarian cancer. Gynecol. Oncol. 2008, 110, 13-21. [CrossRef] [PubMed]

69. Mitchell, P.S.; Parkin, R.K.; Kroh, E.M.; Fritz, B.R.; Wyman, S.K.; Pogosova-Agadjanyan, E.L.; Peterson, A.; Noteboom, J.; O'Briant, K.C.; Allen, A.; et al. Circulating microRNAs as stable blood-based markers for cancer detection. Proc. Natl. Acad. Sci. USA 2008, 105, 10513-10518. [CrossRef] [PubMed]

70. Hunter, M.P.; Ismail, N.; Zhang, X.; Aguda, B.D.; Lee, E.J.; Yu, L.; Xiao, T.; Schafer, J.; Lee, M.-L.T.; Schmittgen, T.D.; et al. Detection of microRNA expression in human peripheral blood microvesicles. PLoS ONE 2008, 3, e3694. [CrossRef] [PubMed]

71. Rabinowits, G.; Gerçel-Taylor, C.; Day, J.M.; Taylor, D.D.; Kloecker, G.H. Exosomal microRNA: A diagnostic marker for lung cancer. Clin. Lung Cancer 2009, 10, 42-46. [CrossRef] [PubMed]

72. Tanaka, Y.; Kamohara, H.; Kinoshita, K.; Kurashige, J.; Ishimoto, T.; Iwatsuki, M.; Watanabe, M.; Baba, H. Clinical impact of serum exosomal microRNA-21 as a clinical biomarker in human esophageal squamous cell carcinoma. Cancer 2013, 119, 1159-1167. [CrossRef] [PubMed]

73. Takeshita, N.; Hoshino, I.; Mori, M.; Akutsu, Y.; Hanari, N.; Yoneyama, Y.; Ikeda, N.; Isozaki, Y.; Maruyama, T.; Akanuma, N.; et al. Serum microRNA expression profile: miR-1246 as a novel diagnostic and prognostic biomarker for oesophageal squamous cell carcinoma. Br. J. Cancer 2013, 108, 644-652. [CrossRef] [PubMed]

74. Eichelser, C.; Stückrath, I.; Müller, V.; Milde-Langosch, K.; Wikman, H.; Pantel, K.; Schwarzenbach, H. Increased serum levels of circulating exosomal microRNA-373 in receptor-negative breast cancer patients. Oncotarget 2014, 5, 9650-9663. [CrossRef] [PubMed]

75. Hannafon, B.N.; Trigoso, Y.D.; Calloway, C.L.; Zhao, Y.D.; Lum, D.H.; Welm, A.L.; Zhao, Z.J.; Blick, K.E.; Dooley, W.C.; Ding, W.Q. Plasma exosome microRNAs are indicative of breast cancer. Breast Cancer Res. BCR 2016. [CrossRef] [PubMed]

76. Liu, C.; Eng, C.; Shen, J.; Lu, Y.; Yoko, T.; Mehdizadeh, A.; Chang, G.J.; Rodriguez-Bigas, M.A.; Li, Y.; Chang, P.; et al. Serum exosomal miR-4772-3p is a predictor of tumor recurrence in stage II and III colon cancer. Oncotarget 2016. [CrossRef] [PubMed]

77. Ogata-Kawata, H.; Izumiya, M.; Kurioka, D.; Honma, Y.; Yamada, Y.; Furuta, K.; Gunji, T.; Ohta, H.; Okamoto, H.; Sonoda, H.; et al. Circulating exosomal microRNAs as biomarkers of colon cancer. PLoS ONE 2014, 9, e92921. [CrossRef] [PubMed] 
78. Bryant, R.J.; Pawlowski, T.; Catto, J.W.F.; Marsden, G.; Vessella, R.L.; Rhees, B.; Kuslich, C.; Visakorpi, T.; Hamdy, F.C. Changes in circulating microRNA levels associated with prostate cancer. Br. J. Cancer 2012, 106, 768-774. [CrossRef] [PubMed]

79. Que, R.; Ding, G.; Chen, J.; Cao, L. Analysis of serum exosomal microRNAs and clinicopathologic features of patients with pancreatic adenocarcinoma. World J. Surg. Oncol. 2013. [CrossRef] [PubMed]

80. Manterola, L.; Guruceaga, E.; Pérez-Larraya, J.G.; González-Huarriz, M.; Jauregui, P.; Tejada, S.; Diez-Valle, R.; Segura, V.; Samprón, N.; Barrena, C.; et al. A small noncoding RNA signature found in exosomes of GBM patient serum as a diagnostic tool. Neuro-Oncology 2014, 16, 520-527. [CrossRef] [PubMed]

81. Thakur, B.K.; Zhang, H.; Becker, A.; Matei, I.; Huang, Y.; Costa-Silva, B.; Zheng, Y.; Hoshino, A.; Brazier, H.; Xiang, J.; et al. Double-stranded DNA in exosomes: A novel biomarker in cancer detection. Cell Res. 2014, 24, 766-769. [CrossRef] [PubMed]

(C) 2017 by the authors; licensee MDPI, Basel, Switzerland. This article is an open access article distributed under the terms and conditions of the Creative Commons Attribution (CC-BY) license (http://creativecommons.org/licenses/by/4.0/). 